\title{
THE LINK BETWEEN SERVICE QUALITY, CORPORATE IMAGE AND BEHAVIORAL INTENTION: SATISFACTION AS AN INTERVENING VARIABLE
}

\author{
Yunita Engriani ${ }^{1}$ \\ Faculty of Economics, Universitas Negeri Padang, Indonesia \\ (Email: yunitaengriani@gmail.com) \\ Meirisa Permatasari ${ }^{2}$ \\ Faculty of Economics, Universitas Negeri Padang, Indonesia \\ (Email: permatasarimeirisa@gmail.com) \\ Abror Abror ${ }^{3 *}$ \\ Faculty of Economics, Universitas Negeri Padang, Indonesia \\ (Email: abror094@gmail.com) \\ ${ }^{*}$ Corresponding Author \\ Dina Patrisia ${ }^{4}$ \\ Faculty of Economics, Universitas Negeri Padang, Indonesia \\ (Email: patrisiadina@yahoo.com.com)
}

Accepted date: $27-01-2019$

Published date: 08-07-2019

To cite this document: Engriani, Y. Permatasari, M., Abror, A., \& Patrisia, D. (2019). The Link Between Service Quality, Corporate Image and Behavioral Intention: Satisfaction as An Intervening Variable. International Journal of Modern Trends in Social Sciences, 2(8), 119131.

DOI: $10.35631 / \mathrm{IJMTSS} .280012$

\begin{abstract}
This study aims to analyze the relationship between service quality, corporate image, customer satisfaction and behavioral intention of Garuda Indonesia Airways' customers. This research also investigates the roles of customer satisfaction as a mediating variable. The population of this study is all customers of Garuda Indonesia Airways. This study employs 150 customers as the respondents. The data collection has been conducted by using a convenience sampling method. This research analyzes the data by using the Structural Equation Modelling (SEM) with Partial Least Square (PLS). After some preliminary tests, this study found that service quality has a positive and significant impact on corporate image and customer satisfaction. Service quality has no significant direct impact on behavioral intention. The corporate image has significantly and positively related to behavioral intention. Customer satisfaction is a significant and positive antecedent of behavior intention. Even though there is no significant direct effect of service quality on behavioral intention, surprisingly, it has a significant indirect impact on behavioral intention through customer satisfaction as an intervening variable. Furthermore, some limitations and further research have been addressed.
\end{abstract}

Keywords: Service Quality, Corporate Image, Behavioral Intention, and Customer Satisfaction 


\section{Introduction}

Indonesia is one of the countries which is experiencing a relatively high growth in the aviation industry. This is supported by Indonesia's geographical condition which is an archipelagic country, even the largest archipelagic country in the world. Indonesia has more than 100,000 islands stretching from Sabang to Merauke. Thus, the geographical conditions make air transportation become one of the main choices of transportation in Indonesia. Garuda Indonesia is one of the Aviation Company in Indonesia which provides a better service by offer the best facilities to increase its customer satisfaction in building behavioral intention.

There are still many problems related to this aviation industry which consumers complain about in Indonesia. Common problems include delay, lack of alertness of employees in overcoming delays, baggage loss or damage and many other problems. So that, customers have considered that the services in the aviation industry in Indonesia are still needed to be improved. Whilst, consumers are the key for the success of a company in industry competition, hence, creating a higher customer value is a primary requirement to make consumers feel satisfied and are expected to be loyal customer. Customers who are satisfied with the performance provided by the company will encourage customers to behave in certain ways. According to Namkung \& Jang (2007) Behavioral Intention is defined by the behavior of customers who are loyal to the company so that they are willing to recommend to others because they have received good service from the company. This is in line with the results of research conducted by Purwati \& Tio (2017) where positive Behavioral intention also has many benefits for the company, one of them is consumers become loyal to the product or services.

Moreover, in creating customer satisfaction, Garuda Indonesia has to provide the best quality services, such as providing a full-service carrier with several facilities, namely: lobby lounge, Garuda Frequent Flyer, etc. In running a Garuda Indonesia business that prioritizes customer satisfaction rather than having to compete with other airlines in lowering prices, Garuda Indonesia offers higher ticket prices with a superior service commitment. Therefore, in improving the service quality, Garuda Indonesia has created the Garuda Indonesia Experience concept. Service quality is the main factor that needs to be considered by Garuda Indonesia such as: carrying out a rejuvenation program for the old fleet, replacing the interior of the aircraft, increasing the ability of employees to provide servants and so on.

Service quality and company image are important points to be considered. The better the quality of service provided by transportation service providers, the more the image of the company will be improved. This means that Garuda Indonesia have to balance the quality of service so that the creation of customer satisfaction and a good corporate image will make customers conduct repurchase and create good behavioral intention. Therefore this study focuses on the Influence of Service Quality, Corporate Image toward Behavioral Intention with Customer Satisfaction as Intervening Variables at Customers PT. Garuda Indonesia (Persero) Tbk in Padang City.

\section{Literature Review}

According to Namkung \& Jang (2007), behavioral intention is the behavior of consumers who are loyal to the company so that they are willing to recommend to others because they get a good service from the company. Moreover, Purwati \& Tio (2017) have stated that the positive behavioral intention also has many benefits for the company. One of them is that it may make 
the consumers become loyal to the product or service used. Furthermore, Kuo \& Tang (2013) said there are several behavioral indicators, namely: (1) Repurchase (2) Word of Mouth (WOM) and (3) Frequency.

To build consumer loyalty and positive behavioral intentions, the first step that must be taken by the company is to create customer satisfaction. According to Kotler \& Keller (2008) customer satisfaction is the feeling of being happy or disappointed from someone towards a product after the customer compares the performance of the product with their expectations. Kuo \& Tang (2017) then added the indicators of customer satisfaction are comparisons between expectations and reality.

Efforts to build customer satisfaction cannot be separated from the efforts of companies to provide good service to customers. According to Tjiptono (2011) service quality is an expected level of excellence where control over the level of excellence aims to meet customer needs. In addition, Loanata (2015) stated the quality of services provided by the company can meet customer expectations and be able to create a good perception of its service image. Furthermore, Aryani \& Rosinta (2010) said that there are several service quality indicators, namely; (1) tangible, for example: Cleanliness of Physical facilities, Neatness of employees, modern or good physical facilities owned. (2) Empathy, Such as: Personal attention, Ease of contacting, Understanding Customer needs. (3) Reliability like Good service from beginning to the end, Administrative accuracy, Service as promised. (4) Responsiveness, such as: Service speed, overcoming difficulties quickly, Employee time. And (5) Assurance, for example: Corporate reputation, Employee competencies, and Employee friendliness.

Besides the efforts in providing excellent service quality which to create customer satisfaction, the company must also be able to build a good corporate image in order to create sustainable excellence. According to Kotler \& Keller (2012) imagery is a set of beliefs, ideas, and impressions that a person has towards an object. Based on Adona (2006) the image of the company is an impression or an image of a company in the eyes of the audience formed based on their own knowledge and experience. Then, Kuo and Tang (2013) used several indicators of corporate image, they are: (1) Reputation (2) Timeliness (3) Companies in the form of safe transportation.

Kuo and Tang (2013) have asserted that customer satisfaction has a direct and significant influence on behavioral intention. In addition, Ryu, et al (2012) also have found that the customer satisfaction is significantly related to behavioral intention. Moreover, the study was conducted by Tahelele (2017) has explained that customer satisfaction has also positively influenced the behavioral intention. Accordingly, we argue the customer satisfaction is an antecedent of customer behavioral intention, therefore, we hypothesize that customer satisfaction has a positive and significant effect on behavioral intention (H1).

Furthermore Chou \& Kim (2009) found that service quality and customer satisfaction have a direct and positive relationship. Moreover, Kuo \& Tang (2013) have asserted that the service quality plays an important and significant role in customer satisfaction. The study was conducted by Tahelele (2017) also has explained that service quality is an important variable which directly influences customer satisfaction. So, from this point of view we posit that the Garuda service quality has a positive and significant effect on customer satisfaction $(\mathrm{H} 2)$. 
Ladhari (2009) found that when customers feel that service quality is good then customers will naturally behave positively by making repeat purchases so that behavioral intention occurs. Accordingly, we might argue that service quality will also has a direct impact on behavioral intention. Saptenno (2011) has added that service quality has a direct, positive and significant influence on behavioral intention. When a customer has perceived a good service quality, it may lead to his/her behavioral intention such as repeat purchase or willing to recommend. From the discussion above, we propose a hypothesis that the service quality has a positive and significant direct effect on behavioral intention $(\mathrm{H} 3)$.

Kuo \& Tang (2013) argue that company image also has a significant relationship to customer satisfaction. Previous research which is conducted by Wu (2014) found that the company's image has a positive effect on customer satisfaction. Furthermore, Tahelele (2017) in his study has explained that corporate image is an important variable that directly affects the customer satisfaction. Arguably, a company with a higher corporate image will have a more possibility to satisfy its customer. Therefore, we propose a hypothesis that company image has a positive and significant effect on customer satisfaction (H4).

The study was conducted by $\mathrm{Wu}$ (2014) found that the company's image is also directly related to behavioral intention. Then supported by Mukhlison et al. (2016) who stated that the company's image has a significant influence on behavioral intention. Moreover, Tahelele (2017) revealed that a good corporate image will form a positive relationship to behavioral intention. Hence, we propose the fifth Hypothesis (H5) that corporate image has a positive and significant effect on behavioral intention.

Chou \& Kim (2009) explain that service quality is a fundamental driver of corporate image. Therefore, active monitoring and management of service quality needs to be made a component for the company's image. The study was conducted by Kuo \& Tang (2013) found that the service quality is positively related to the company image. Finally, we posit the last hypothesis (H6) of this study that the service Quality has a positive and significant effect on Company Image.

Based on the theory and literature above, the conceptual framework for this study can be created as follow:

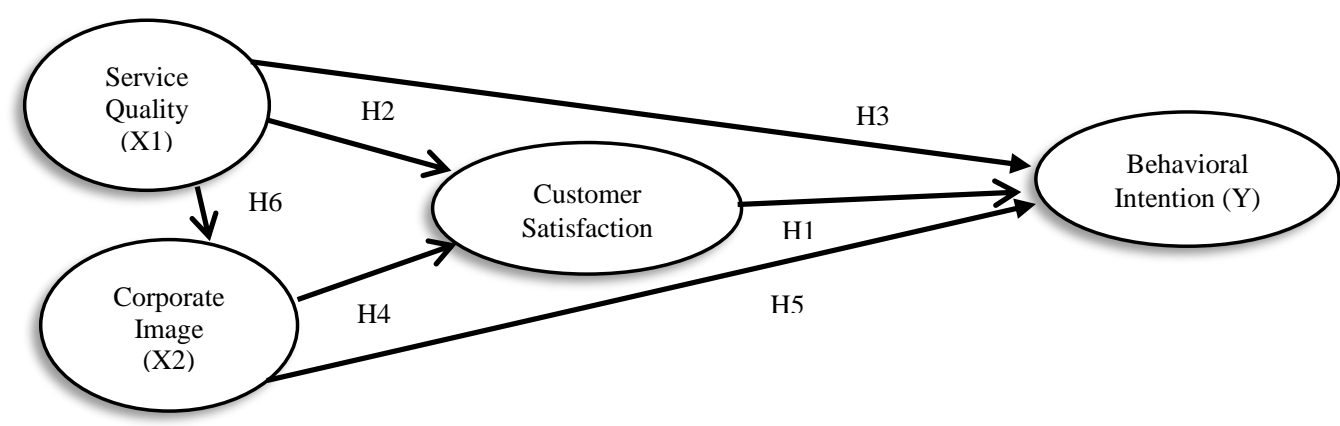

Figure 1: Research Model

H1 = Customer satisfaction has a positive and significant effect on behavioral intention

H2 = service quality has a positive and significant effect on customer satisfaction.

H3 = Service quality has a positive and significant effect on behavioral intention. 
H4 = Company image has a positive and significant effect on customer satisfaction.

H5 = Corporate image has a positive and significant effect on behavioral intention.

H6 = Service Quality has a positive and significant effect on Corporate Image.

\section{Research Methodology}

This research is a causative research. This study explains the relationship between Service Quality, Corporate Image and Behavioral Intention. In addition, we employed the customer Satisfaction as an intervening variable. Population of this study is all passenger of PT. Garuda Indonesia (Persero) Tbk in Padang City. The amount of sample is 150 which is taken by using purposive sampling technique with criteria considered by the people in Padang City who have used Garuda airlines. We analyze the data by using the Structural Equation Model (SEM) using the Partial Least Square (PLS) and SmartPLS version 3.2.7. Furthermore, some preliminary analyses, such as outlier, validity and reliability test have been applied (Wardi, Abror, \& Trinanda, 2018; Hair, Black, Babin, \& Anderson, 2010).

\section{Result and Discussion}

\section{Result}

\section{Descriptive Variable Statistics}

This study has conducted descriptive statistical analysis to get some general information, such as mean value of variables and the respondent characteristics. The results can be seen as follow:

\section{Table 1. Results of The Average Assessment Criteria}

Source: Primary Data (Research findings)

\begin{tabular}{|l|l|}
\hline Variable & Mean \\
\hline Service Quality & 3.82 \\
\hline Corporate Image & 3.96 \\
\hline $\begin{array}{l}\text { Customer } \\
\text { Satisfaction }\end{array}$ & 3.86 \\
\hline $\begin{array}{l}\text { Behavioral } \\
\text { Intention }\end{array}$ & 4.00 \\
\hline
\end{tabular}

\section{Evaluation Outer Model}

Convergent validity is determined by using the loading factor / outer loading value parameter and the AVE (Average Variance Extracted) value. Measurement can be categorized as having good convergent validity if the value of outer loading $>0.6$ and the value of AVE> 0.5 (Ghozali \& Latan, 2012). Table 2 shows the loading factors of 25 indicators which is used in this study:

Table 2. Outer Loading

\begin{tabular}{|l|l|l|c|c|}
\hline Variable & No & Indicator & $\begin{array}{l}\text { Outer loading } \\
(>, 06)\end{array}$ & Explanation \\
\hline \multirow{3}{*}{$\begin{array}{l}\text { Service } \\
\text { Quality }\end{array}$} & 1 & KPT1 & 0,782 & Valid \\
\cline { 2 - 5 } & 2 & KPT2 & 0,689 & Valid \\
\cline { 2 - 5 } & 3 & KPT3 & 0,751 & Valid \\
\cline { 2 - 5 } & 4 & KPEM1 & 0,599 & Valid \\
\hline
\end{tabular}




\begin{tabular}{|c|c|c|c|c|}
\hline & 5 & KPEM2 & 0,653 & Valid \\
\hline & 6 & KPEM3 & 0,673 & Valid \\
\hline & 7 & KPR1 & 0,642 & Valid \\
\hline & 8 & KPR2 & 0,673 & Valid \\
\hline & 9 & KPR3 & 0,580 & Valid \\
\hline & 10 & KPRES1 & 0,741 & Valid \\
\hline & 11 & KPRES2 & 0,723 & Valid \\
\hline & 12 & KPRES3 & 0,692 & Valid \\
\hline & 13 & KPAS1 & 0,684 & Valid \\
\hline & 14 & KPA2 & 0,710 & Valid \\
\hline & 15 & KPA3 & 0,539 & Valid \\
\hline \multirow{4}{*}{$\begin{array}{l}\text { Corporate } \\
\text { Image }\end{array}$} & 16 & CP1 & 0,821 & Valid \\
\hline & 17 & $\mathrm{CP} 2$ & 0,830 & Valid \\
\hline & 18 & CP3 & 0,816 & Valid \\
\hline & 19 & $\mathrm{CP} 4$ & 0,848 & Valid \\
\hline \multirow{3}{*}{$\begin{array}{l}\text { Customer } \\
\text { Satisfaction }\end{array}$} & 20 & KEPE1 & 0,860 & Valid \\
\hline & 21 & KEPE2 & 0,872 & Valid \\
\hline & 22 & KEPE3 & 0,750 & Valid \\
\hline \multirow{3}{*}{$\begin{array}{l}\text { Behavioral } \\
\text { Intention }\end{array}$} & 23 & BI1 & 0,873 & Valid \\
\hline & 24 & BI2 & 0,844 & Valid \\
\hline & 25 & $\mathrm{BI} 3$ & 0,868 & Valid \\
\hline
\end{tabular}

Source: Primary Data (Research Finding)

Table 2 shows 25 valid indicators. According to Hussein (2015), if there is an outer loading value below 0.6, the indicator can be omitted because it does not represent the existing construct. So that this study has no indicator which will be eliminated because all of them are valid. Therefore, the following figure shows the research model with the path diagram for all indicators:

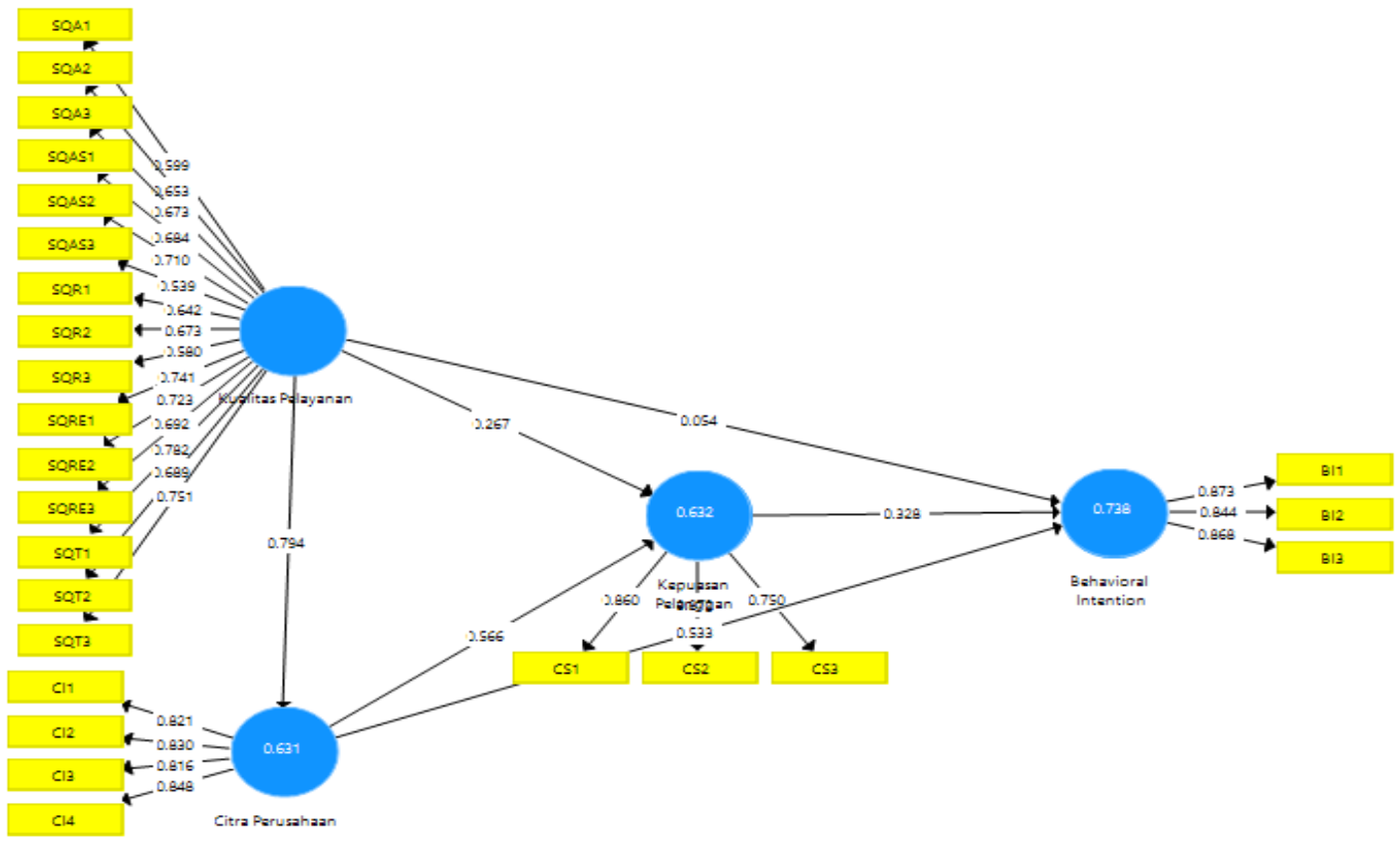

Figure 2: Research Model 


\section{Discriminant Validity}

We have tested the discriminant validity by using Fornell Larkers's criteria. The indicators that have been derived from different constructs should not be highly correlated (Ghozali \& Latan, 2012).

Table 3. Discriminant Validity

\begin{tabular}{lllll}
\hline Variable & BI & CI & SQ & CS \\
\hline $\begin{array}{l}\text { Behavioral } \\
\text { Intention }\end{array}$ & $\mathbf{0 , 8 6 2}$ & & & \\
$\begin{array}{l}\text { Company } \\
\text { image }\end{array}$ & 0,831 & $\mathbf{0 , 8 2 9}$ & & \\
$\begin{array}{l}\text { Service } \\
\text { Quality } \\
\text { Customer } \\
\text { Satisfaction }\end{array}$ & 0,781 & 0,778 & $\mathbf{0 , 8 2 9}$ & \\
\hline
\end{tabular}

Source: Primary Data (Research Finding)

Table 3 shows that the values of square root of AVE in the diagonal are greater than the correlation values in the column. Hence, it means that all variables in this study are valid.

\section{Average Variance Extracted (AVE)}

The convergent validity of the measurement model is also seen from the AVE value. AVE value describes the magnitude of the diversity of the manifest/indicator variables contained in the construct. Based on Ghozali and Latan (2012), the use of AVE values is needed in convergent validity test. Furthermore, the recommended AVE value is at least 0.5 to indicate a good convergent validity.

Table 4. AVE value (Average Variance Extracted)

\begin{tabular}{ll}
\hline Variable & $\begin{array}{l}\text { Value AVE } \\
(>0,5)\end{array}$ \\
\hline Service quality(X1) & 0,460 \\
Corporate Image(X2) & 0,686 \\
Customer Satisfaction & 0,688 \\
(Z) & \\
Behavioral Intention & 0,743 \\
$(\mathrm{Y})$ & \\
\hline
\end{tabular}

Source: Primary Data (Research Founding)

Table 4 shows that the service quality has a lower AVE value than 0.5 . It can be stated that more than half of the variants in each indicator of this study has good convergent validity.

\section{Composite Reliability}

We have also examined the composite reliability value of the data. The criterion is that value should be equal or greater than 0.7 . We found that all the constructs have so that, the variable can be said to be reliable (Hussein, 2015). The following is a results of composite reliability values: 
Table 5. Composite Reliability Value

\begin{tabular}{lll}
\hline \multicolumn{1}{c}{ Variable } & Composite Realibity $(>0,7)$ & Explanation \\
\hline Service quality $(\mathrm{X} 1)$ & 0,927 & Reliable \\
Corporate Image $(\mathrm{X} 2)$ & 0,898 & Reliable \\
Customer Satisfaction $(\mathrm{Z})$ & 0,869 & Reliable \\
Behavioral Intention $(\mathrm{Y})$ & 0,896 & Reliable \\
\hline
\end{tabular}

Source: Primary Data (Research Founding)

Table 5 describes each variable in this study has a good composite reliability value which is greater than 0.7. Therefore, each variable in this study have fulfilled the requirements that have a level of reliability in accordance with the specified conditions.

\section{Inner Model Evaluation}

Evaluating the inner model or structural model aims to see the direct or indirect influence between variables. Evaluation of the structural model can be started by looking at the R-square value in endogenous latent variables. According to Ghozali and Latan (2012), the R-square value of $0.75,0.5$ and 0.25 defines the model as strong, moderate and weak in explaining the effect of exogenous latent variables on endogenous latent variables.

Table 6. $R$-Square Value

\begin{tabular}{lcc}
\hline \multicolumn{1}{c}{ Variable } & R-Square & Information \\
\hline $\begin{array}{l}\text { Behavioral } \\
\text { Intention }\end{array}$ & 0,738 & Strong \\
Corporate Image & 0,631 & Moderate \\
Customer & 0,632 & Moderate \\
Satisfaction & & \\
\hline
\end{tabular}

Source: Primary Data (Research Founding)

Table 6 illustrates that the value of R-Square for behavioral intention variable is 0.738 , this indicates that the service quality, company image, and customer satisfaction have explained $73.8 \%$ of behavioral intention variation, whilst, the remaining $26.2 \%$ are affected by other factors. Furthermore, the value of R-Square Company Image of 0.631, hence, this indicates that the influence of service quality on corporate image is $63.1 \%$. Finally, $63.2 \%$ of the customer satisfaction has been affected by service quality and corporate image.

\section{Hypothesis Testing}

Table 7 shows the hypotheses testing. Based on the results, we found that only one hypothesis (out of 6) is not significant. Service quality has no direct significant relationship with behavioral intention. However, it has significant indirect relationship through customer satisfaction and corporate image as the mediator.

Table 7. Hypothesis Testing

\begin{tabular}{lllll}
\hline & $\begin{array}{l}\text { Path } \\
\text { coefficient }\end{array}$ & T Statistic & P Value & Information \\
\hline $\begin{array}{l}\text { Customer } \\
\text { Satisfaction-> }\end{array}$ & 0,328 & 3,874 & 0,000 & H1 accepted \\
Behavioral Intention & & & & \\
\hline
\end{tabular}




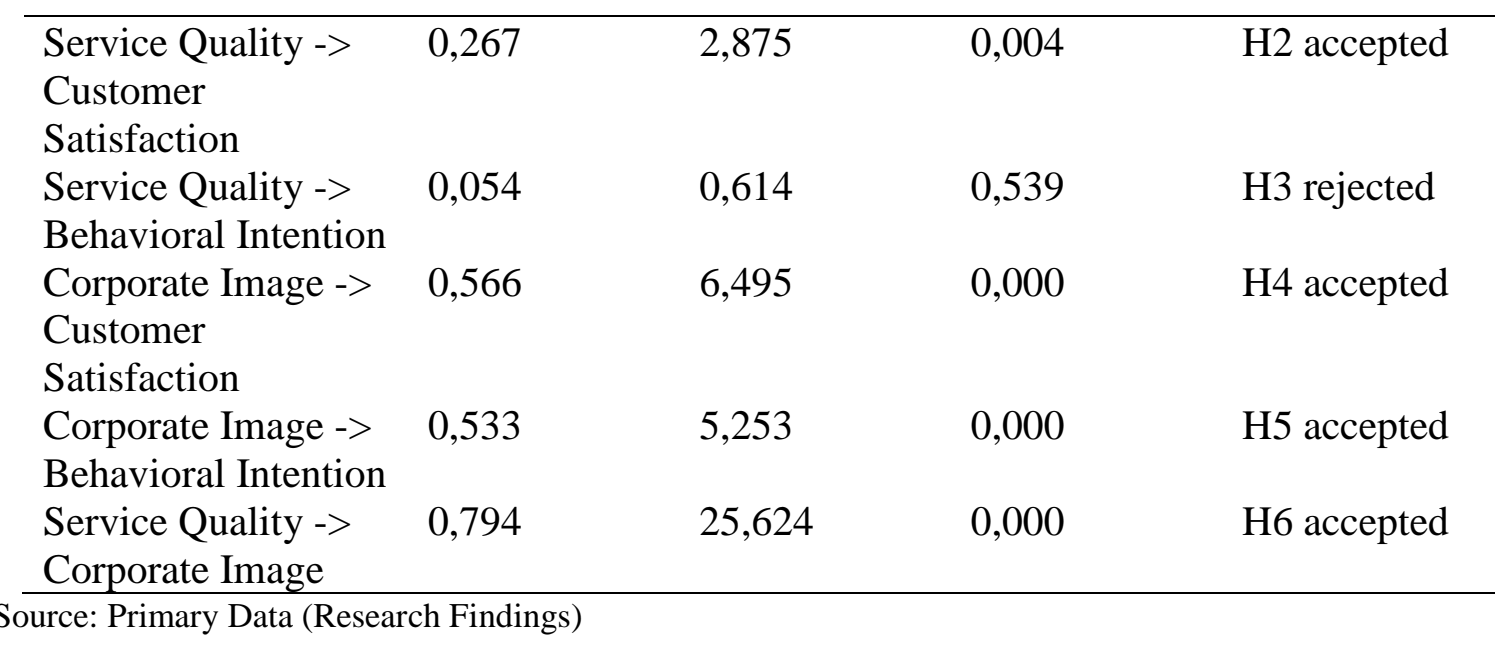

\section{Discussion}

Base on the results, it can be explained as follows:

1. A positive and significant relationship between customer satisfaction and behavioral intention in PT. Garuda Indonesia (Persero) Tbk in Padang City. The result of this study is in accordance with previous studies, such as Tahelele (2017), who has claimed that the satisfaction felt by customers has a positive impact on customer behavior intentions. Furthermore, Mukhlison et al. (2016) have explained that customer satisfaction also has a significant effect on behavioral intention. In addition, Kuo \& Tang (2013) said that customer satisfaction has a direct influence on behavioral intention. And according to $\mathrm{Wu}$ (2014) in his research explained that customer satisfaction is related to behavioral intention. In the results of this study there is a positive relationship between customer satisfaction and behavioral intention of the customers of PT. Garuda Indonesia (Persero) Tbk. The implication is that the company has to increase customer satisfaction by listening to customers wishes and improving employee performance so that the creation of customer satisfaction and itself will create behavioral intention because if customers are satisfied with the performance provided by Garuda Indonesia, customers will conduct repurchase activities and use Garuda Indonesia repeatedly and customers will definitely recommend Garuda Indonesia to their closest relatives, friends and family to use Garuda Indonesia airlines.

2. This study found a positive and significant relationship between service quality and customer satisfaction of PT Garuda Indonesia (Persero) Tbk. The result of this study supports some previous studies, such as Chou \& Kim (2009) who has examined a positive and significant relationship between service quality and customer satisfaction. According to Kuo \& Deng (2009), service quality also has a positive impact on customer satisfaction. Tahelele (2017) explained that service quality is an important variable that directly affects customer satisfaction. Moreover, Kuo \& Tang (2013) found service quality plays an important and significant role in customer satisfaction. In the results of this study there is a positive relationship between service quality and customer satisfaction in the customers of PT. Garuda Indonesia (Persero) Tbk in Padang City. The implication is that companies have to provide the best service to customers by providing full service carrier and several good facilities such as lobby lounge and Garuda Frequent Flyer for customers who are loyal to Garuda Indonesia. By offering customer based on what they likes or tastes make customers feel satisfied with the services provided by Garuda Indonesia airlines. 
3. Service quality have a positive effect, however, it is not significantly influence behavioral intention of customers PT. Garuda Indonesia (Persero) Tbk, this result is inversely proportional to previous research conducted by Saptemo (2011), who has explained that service quality has an effect on behavioral intention. However, even though the service quality has no direct significant relationship to behavioral intention, it has a positive and significant indirect relationship to behavioral intention through customer satisfaction and corporate image as the mediator. This finding is in line with Tahelele (2017) who argue that service quality will lead to customer satisfaction before it has an impact on behavioral intention.

4. There is a positive and significant relationship between corporate image and customer satisfaction of PT. Garuda Indonesia (Persero) Tbk. This result is congruent with Kuo \& Tang (2013) who assert that corporate image is a significant antecedent of customer satisfaction. Moreover, Mukhlison, et al (2016) have examined a significant effect of corporate image on customer satisfaction. Accordingly, a better corporate image will lead to a better customer satisfaction. Therefore, the Garuda Indonesia has to build its corporate image which is different with other airlines.

5. Corporate image also has a significant and positive impact on behavioral intention. The result of this study supports some previous studies. For example, Wu (2014) has investigated a significant and positive impact of corporate image on customer behavioral intention. Furthermore, Mukhlison, et al (2016) have also found that corporate image has a significant influence on behavioral intention. The implication is that company has to create corporate image building program, such as recruiting high competencies flight attendants. By having good management, a good corporate image will be formed. With a good corporate image will make customers believe in the company and customers who believe in the company will create loyalty so that customers themselves will recommend Garuda Indonesia to others. The image of PT. Garuda Indonesia that is currently good in the eyes of customers have to provide a customer-focused strategy by providing the best service to customers. If customers are satisfied with the services provided by Garuda Indonesia, they will automatically conducts a repurchase and travel by using Garuda Indonesia for the next.

6. There is a Positive and significant relationship between service quality and company image in PT. Garuda Indonesia (Persero) Tbk in Padang City. The results of this study are consistent with previous studies conducted by Chou \& Kim (2009) explaining that service quality is a fundamental driver of corporate image. And according to Kuo \& Tang (2013) said that there is a positive relationship between service quality and corporate image. While according to $\mathrm{Wu}$ (2014) service quality is directly related to corporate image. In the results of this study there is a positive relationship between service quality and company image in the customers of PT. Garuda Indonesia (Persero) Tbk in Padang City. The implication is that companies must actively monitor and manage service quality to improve a good corporate image. Service quality and good image of Garuda Indonesia are things that need to be considered by the company. The better quality of service provided by the company, the better the image of the company as well.

\section{Conclusion}

The conclusion of this study is:

1. There is a significant and positive influence of Customer Satisfaction on Behavioral Intention of customers PT. Garuda Indonesia (Persero). 
2. There is the influence of service quality on customer satisfaction of customers PT. Garuda Indonesia (Persero) Tbk in Padang City, the hypothesis can be accepted or proven and these findings support and provide reinforcement in previous studies.

3. Variable service quality does not have a significant and positive effect on behavioral intention on customers PT. Garuda Indonesia (Persero) Tbk in Padang City, but the service quality has a significant and positive influence on behavioral intention through customer satisfaction.

4. There is the influence of corporate image on customer satisfaction of customers PT. Garuda Indonesia (Persero) Tbk in Padang City, this research hypothesis can be accepted or proven and these findings support and provide reinforcement in previous studies.

5. There is the influence of corporate image on behavioral intention of customers PT. Garuda Indonesia (Persero) Tbk in Padang City, this research hypothesis can be accepted or proven and these findings support and provide reinforcement in previous studies.

6. There is the influence of service quality on the company's image of the customers PT. Garuda Indonesia (Persero) Tbk in Padang City, this research hypothesis can be accepted or proven and these findings support and provide reinforcement in previous studies.

\section{Reference}

Aryani, D., \& Rosinta, F. (2010). "Pengaruh kualitas layanan terhadap kepuasan pelanggan dalam membentuk loyalitas pelanggan". Bisnis \& Birokrasi Journal, 17(2).

Adona, F. (2006) . Citra dan Kekerasan dalam Iklan Perusahaan di Televisi. Padang: Andalas University Press.

Chen, C. F. \& Tsai, D. (2007). How destination image and evaluative factors affect behavioral intentions?. Touris management, 28(4), 1115-1122.

Chou, J. S., \& Kim, C. (2009). A structural equation analysis of the QSL relationship with passenger riding experience on high speed rail: An empirical study of Taiwan and Korea. Expert Systems with Applications, 36(3), 6945-6955.

Ghozali, Imam. (2009). Aplikasi Analisis Multivariate Dengan Program SPSS. Semarang: UNDIP.

Haryono, S. (2015). Konsep Dasar PLS. In Konsep Dasar PLS.

Hair, J. F., Black, W. C., Babin, B. J., \& Anderson, R. E. (2010). Multivariate data analysis. New Jersey: Prentice Hall.

Indriantoro, N., \& Supomo, B. (2002). Metodologi Penelitian Bisnis untuk Manajemen dan Akuntansi. Yogyakarta: BPFE.

Idris. (2013). Aplikasi Model Analisis Data Kuantitatif dengan Program SPSS. Padang: UNP Irawan, H. (2010). Prinsip kepuasan pelanggan. Jakarta: PT. Elex Media Komputindo.

Jaya, I. G., \& Sumertajaya, I. M. (2008). Pemodelan Persamaan Struktural Dengan Partial Least Square. In Semnas Matematikan dan Pendidikan Matematika.

Koivumäki T, Ristola A, Kesti M. (2008). The effects of information quality of mobile services on user satisfaction and service acceptance - empirical evidence from Finland. Behavior and Information Technology, 27:375-385.

Kotler \& Philip. (2008). Managemen pemasaran. Alih bahasa: Drs. Benyamin Molan. Edisi Koran. Jilid 1. Pt. IkrarMandiriAbadi: Jakarta.

Kotler, P. \& Keller, K.L. (2009). Marketing management (13th ed.). New Jersey: Pearson Prentice-Hall. 
Kotler \& Keller. (2012). Marketing Management edisi 14, Global Edition. Pearson Prentice Hall.

Kuo, Y. F., Wu, C. M., \& Deng, W. J. (2009). The relationships among service quality, perceived value, customer satisfaction, and post-purchase intention in mobile valueadded services. Computers in human behavior, 25(4), 887-896.

Kuo, C. W., \& Tang, M. L. (2013). Relationships among service quality, corporate image, customer satisfaction, and behavioral intention for the elderly in high speed rail services. Journal of Advanced Transportation, 47(5), 512-525.

Ladhari, R. (2009). Service quality, emotional satisfaction, and behavioural intentions: A study in the hotel industry. Managing Service Quality: An International Journal, 19(3), 308-331.

Lesmana, R \& Yustriani . (2017). Pengaruh citra perusahaan terhadap keputusan pembelian konsumen pt. Garuda indonesia tbk. (persero). (jurnal ilmiah manajemen forkamma), vol.1, no.1.

Lupioyadi \& Rambat. (2001). Manajemen Pemasaran Jasa. Jakarta: Salemba Empat.

Loanata, I. A., Dasmasela, K. N., \& Soelistyo, E. E. (2015). Analisis Pengaruh Service Quality Terhadap Behavioral Intentions Dengan Customer Satisfaction Sebagai Variabel Intervening Di Amaris Hotel Surabaya. Jurnal Hospitality dan Manajemen Jasa, 3(2), 199-213.

Mowen C, John dan Michael Minor. (2002). Perilaku Konsumen, Jilid 2

Muliaty. (2016). "faktor-faktor yang mempengaruhi kualitas pelayanan pada politeknik negeri media kreatif makassar". Jurnal Administrasi Publik, Volume 6 No. 1.

Mukhlison, E., \& Saputra, S. D. (2016). Peran Kepuasan Pelanggan Sebagai Pemediasi Pada Pengaruh Citra Restoran Terhadap Behavioral Intention. Ekonomi dan Kewirausahaan, 16(1).

Namkung, Y. \& Jang, S. (2007). Does food quality really matter in restaurant?: its impact on customer satisfaction and behavioral intentions. Journal of Hospitality and Tourism Research, Vol. 31 No. 3, pp. 387-410.

Purwianti, L., \& Tio, K. (2017). Faktor-Faktor Yang Mempengaruhi Behavioural Intention. Jurnal Manajemen Maranatha, 17(1), 15-32.

Rangkuti, F. (2006). Measuring customer satisfaction (teknik mengukur dan strategi meningkatkan kepuasan pelanggan), penerbit PT. Gramedia Pustaka Utama, Jakarta.

Ryu, K., Lee, H. R., \& Gon Kim, W. (2012). The influence of the quality of the physical environment, food, and service on restaurant image, customer perceived value, customer satisfaction, and behavioral intentions. International Journal of Contemporary Hospitality Management, 24(2), 200-223.

Saha, G. C., \& Theingi. (2009). Service quality, satisfaction, and behavioural intentions: A study of low-cost airline carriers in Thailand. Managing Service Quality: An International Journal, 19(3), 350-372.

Sugiyono. (2010). Metode Penelitian Kuantitatif Kualitatif dan R\&amp;D. Bandung: CV. Alfabeta.

Saptenno, Sammy (2011), "Analisis Kualitas, Merek, Nilai, dan Kepuasan Nasabah Dalam Membentuk Niat Berperilaku Nasabah Bank di Kota Ambon". Disertasi Program Pascasarjana Universitas Hasanudin, Tidak dipublikasikan, Makassar.

Syahron, L. (2011). Metodologi Penelitian Pendidikan. Padang: Sukabina Press.

Sugiyono. (2012). Metode Penelitian Kuantitif Kualitatif dan R\&D. Bandung: CV. Alfabeta.

Suharsimi. (2014). Prosedur Penelitian Suatu Pendekatan Praktek. Jakarta: Rineka Cipta. 
Saktiani, Garnis Anggi. (2015). Pengaruh Kualitas Layanan Dan Citra Perusahaan Terhadap Kepuasan Pelanggan Dan Word Of Mouth, Jurnal Ilmu Sosial Dan Ilmu Politik. Vol.4 No.2.

Tsaur, S. H., Chang, T. Y., \& Yen, C. H. (2002). The evaluation of airline service quality by fuzzy MCDM. Tourism management, 23(2), 107-115.

Tang, W. W. (2010). Impact Of Corporate Image And Corporate Reputation On Customer Loyalty: A Review. Management Science And Engineering, 1(2), 57-62.

Tjiptono, Fandy. (2011). Service Quality \& Satisfaction. Edisi 3. Yogyakarta: C.V Andi.

Tahalele, M. C. (2017). Pengaruh Kualitas Layanan, Citra Hotel terhadap Kepuasan yang Berdampak pada Niat Berperilaku Pelanggan Hotel Amboina di Kota Ambon. Jurnal Penelitian Manajemen Terapan (PENATARAN), 2(2), 127-142.

Usmara, U. (2008). Pemikiran Kreatif Pemasaran, cetakan pertama, Penerbit:Amara Books.

Wardi, Y., Abror, A., \& Trinanda, O. (2018). Halal tourism: antecedent of tourist's satisfaction and word of mouth (WOM). Asia Pacific Journal of Tourism Research, 23(5), 463-472. doi: 10.1080/10941665.2018.1466816

$\mathrm{Wu}, \mathrm{H}$. C. (2014). The effects of customer satisfaction, perceived value, corporate image and service quality on behavioral intentions in gaming establishments. Asia Pacific Journal of Marketing and Logistics, 26(4), 540-565.

Yee, R. W., Yeung, A. C., \& Cheng, T. E. (2008). The impact of employee satisfaction on quality and profitability in high-contact service industries. Journal of operations management, 26(5), 651-668.

Zeithaml, V. A., Bitner, M. J., \& Gremler, D. D. (2010). Services marketing strategy. Wiley International Encyclopedia of Marketing. 